\begin{tabular}{|c|c|c|}
\hline $\begin{array}{c}\text { Proceeding } \\
\text { SALATIGA }\end{array}$ & $\begin{array}{c}\text { Procember 2021 } \\
\text { E-ISSN: 2827-9581 } \\
\text { Website: http://conference.iainsalatiga.ac.id/index.php/iciegc }\end{array}$ & HIm. 241-256 \\
\hline
\end{tabular}

\title{
RELIGIOUS COUNSELING PARADIGM IN THE CONTEXT OF INDONESIA CULTURE (ALTERNATIF APPROACH IN THE ERA OF INDUSTRIAL 4.0)
}

\author{
Wahidin', Sya'ban Maghfur ${ }^{2}$ \\ ${ }^{1,2}$ IAIN Salatiga
}

\begin{tabular}{l}
\hline \hline Informasi Artikel \\
\hline Penulis Korespondensi: \\
Wahidin \\
Email: weaidin@ gmail.com
\end{tabular}

\begin{abstract}
The majority of Indonesia's population believes in the existence of God and believes that religion contributes to physical and mental health. The purpose of this study is to describe the theoretical framework of religious counseling within the context of Indonesian culture. Qualitative research approaches library research and content analysis as data analysis techniques. The results were obtained that the paradigm of religious counseling within the context of Indonesian culture as an alternative approach in the industrial era 4.0. The paradigm is meant in the form of philosophical, regulative, empirical, psychological, and sociological foundations for the implementation of religious counseling. Religious competence becomes a fundamental discourse for the realization of professional counselors as an alternative guidance and counseling service in the industrial era 4.0 in the millennial generation.
\end{abstract}

\begin{tabular}{l} 
Keyword: Religious counseling; nation culture; religius \\
competency; 4.0 industrial era \\
\hline ABSTRAK \\
\hline Mayoritas penduduk Indonesia percaya akan adanya Tuhan dan \\
percaya bahwa agama berkontribusi terhadap kesehatan fisik dan \\
mental. Tujuan dari penelitian ini adalah untuk mendeskripsikan \\
kerangka teori konseling agama dalam konteks budaya Indonesia. \\
Penelitian kualitatif menggunakan pendekatan penelitian \\
kepustakaan dan analisis isi sebagai teknik analisis data. Hasil yang \\
diperoleh bahwa paradigma penyuluhan agama dalam konteks \\
budaya Indonesia sebagai pendekatan alternatif di era industri 4.0. \\
Paradigma dimaksud berupa landasan filosofis, regulatif, empiris, \\
psikologis, dan sosiologis bagi pelaksanaan konseling agama. \\
Kompetensi keagamaan menjadi wacana mendasar bagi terwujudnya \\
konselor profesional sebagai alternatif layanan bimbingan dan \\
konseling di era industri 4.0 pada generasi milenial.
\end{tabular}

Kata kunci: Konseling religius; budaya nasional; kompetensi religius; era industri 4.0

\section{PENDAHULUAN}

Indonesia adalah bangsa religius (religious nation state) atau negara kebangsaan yang dijiwai oleh agama. Bukti konkret sebagai bangsa religius adalah mayoritas penduduk Indonesia memeluk agama atau menganut kepercayaan kepada Tuhan Yang Maha Esa. 
Secara eksplisit konstitusi negara menjamin kemerdekaan tiap-tiap penduduk untuk memeluk agamanya masing-masing dan untuk beribadat menurut agamanya dan kepercayaannya. Secara legal konstitusi di Indonesia mengakui enam agama resmi, yaitu Islam, Kristen, Katolik, Hindu, Budha, dan Konghucu. Di luar keenam agama tersebut sebagian penduduk Indonesia menganut keyakinan kepercayaan yang berbeda-beda.

Bukti lain sebagai bangsa religius tercermin dari Pembukaan Undang-Undang Dasar (UUD) 1945 dan Pancasila. Alinea ketiga Pembukaan UUD 1945 menyebutkan bahwa “atas berkat rahmat Allah Yang Maha Kuasa dan dengan didorongkan oleh keinginan luhur, supaya berkehidupan kebangsaan yang bebas, maka rakyat Indonesia menyatakan dengan ini kemerdekaannya." Kandungan teks tersebut dipahami bahwa pendiri bangsa mengakui adanya rahmat Allah dalam perjalanan bangsa, dan sebagai ungkapan rasa syukur kepada Tuhan dituangkan dalam Pembukaan UUD RI 1945. Dalam konteks ini, dipahami bahwa Indonesia adalah bangsa yang menjunjung tinggi nilai-nilai religius dan spiritual (Pambudi, 2018). Keyakinan kepada Tuhan dalam kehidupan berbangsa dan bernegara diwujudkan melalui sila pertama Pancasila, "Ketuhanan Yang Maha Esa". Diksi tersebut mengandung makna bahwa Indonesia adalah negara yang secara etis dan moral mengakui keberadaan Tuhan. Sila pertama ini menegaskan bahwa landasan utama dalam kehidupan berbangsa dan bernegara adalah pengakuan adanya Tuhan (Kamaruddin, 2013).

Kedua landasan konstitusi berbangsa dan bernegara sebagaimana diuraikan di atas memberi makna bahwa negara Indonesia adalah negara yang menjunjung tinggi nilainilai religius. Bangsa Indonesia tidak menghendaki perwujudan negara agama (religious state), tetapi juga tidak menghendaki perwujudan negara sekuler (secular state) (Fanani, 2008). Negara agama menempatkan ajaran agama (syariat) sebagai konstitusi bernegara, sedangkan negara sekuler ketidakpedulian negara dengan urusan agama penduduknya. Secara dejure dan defacto, Indonesia sangat memperhatikan kehidupan agama, sebagai buktinya konstitusi negara sebagaimana disebutkan di atas dan kepedulian negara mengurusi agama yang diwujudkan melalui kementerian agama.

Pengaruh agama yang kuat dalam kehidupan berbangsa dan bernegara berimplikasi terhadap orientasi tujuan pendidikan yang dicita-citakan oleh bangsa Indonesia. Orientasi pendidikan nasional sebagaimana amanat Undang-Undang Nomor 20 Tahun 2003 tentang Sistem Pendidikan adalah untuk mengembangkan potensi peserta didik untuk memiliki spiritual keagamaan, pengendalian diri, kepribadian, kecerdasan, akhlak mulia. Undangundang tersebut menegaskan bahwa tujuan pendidikan nasional untuk mengembangkan 
potensi peserta didik agar menjadi manusia yang beriman dan bertaqwa kepada Allah Swt, berakhlak muliah, sehat, berilmu, cakap, kreatif, mandiri dan menjadi warga negara yang demokratis serta bertanggungjawab.

Sebagai bangsa yang orientasi dan tujuan pendidikan untuk mengembangkan potensi peserta didik menjadi manusia yang beriman dan bertakwa kepada Allah Swt dan berakhlak mulia, maka paradigma penerapan pembelajaran yang mengakuai adanya Tuhan mutlak diperlukan. Pendidikan dengan paradigma seperti itu diharapkan membentuk manusia seutuhnya (Dahlan, 2011). Manusia seutuhnya diartikan sebagai kesadaran insani untuk mengabdi secara total pada kebaikan karena menyadari peranya sebagai hamba Tuhan dan khalifah Allah di muka bumi.

Dalam praktiknya, membentuk manusia seutuhnya sebagai pribadi ideal tidaklah mudah. Paradigma seperti itu dapat terwujud apabila proses pendidikan menyeimbangkan potensi (fitrah) manusia secara total. Potensi yang dimaksud disini adalah fitrah iman, jasmani, ruhani, dan nafs (Sutoyo, 2007). Esensi dari fitrah iman adalah pengakuan keesaan dan ketundukan pada Tuhan. Iman berfungsi memberi bentuk dan arah bagi potensi lainya. Sementara itu esensi fitrah jasmani adalah sebagai wadah bersemayam bagi ketiga potensi lainya saat di dunia. Selanjutnya esensi fitrah ruhani sebagai perwujudan pribadi manusia untuk memperjuangkan dimensi spiritual atau kesucian. Sedangkan potensi nafs sebagai pemandu integral antara fitrah jasmani dengan fitrah ruhani. Komponen nafs terdiri dari qalb (hati), aql (akal), dan nafsu (syahwat) yang saling berinteraksi dalam membentuk kepribadian. Dari keempat potensi tersebut, iman lah sebagai panglima untuk menghantarkan derajat kemuliaan manusia dan kesempurnaan hidupnya.

Bertolak dari fitrah yang dimiliki manusia, idealnya manusia hidup lurus sesuai tuntunan yang diajarkan agama maupun norma sosial-masyarakat. Akan tetapi fenomena yang ditunjukkan oleh manusia tidak semuanya berjalan sesuai fitrah yang diberikan kepadanya. Sebagian manusia hidup dikuasai nafsu (syahwat), sehingga menimbulkan perilaku amoral, asusila, dan kejahatan. Banyak manusia mementingkan materi (materialis) dan memuaskan nafsu syahwat (hedonis). Kondisi seperti ini diperparah dengan hadirnya era modern atau yang dikenal dengan era revolusi industri 4.0. Ciri utama era industri 4.0 adalah kecerdasan buatan (artificial intelligence) yang menguasai kehidupan manusia, seperti super komputer, teknologi nano, mobil otomatis, serta inovasi dalam berbagai bidang khususnya pada bidang industri. Pada era ini semakin terlihat wujud dunia yang telah 
menjadi "kampung global". Kemajuan ilmu pengetahuan di berbagai bidang telah membawa umat manusia menjadi satu kesatuan (Satya, 2018).

Pada kondisi seperti itu, problem terbesar yang diharapi manusia pada era modern adalah alienasi dan dehumanisasi (Ulfiah, 2018). Aliensi merupakan problem kehidupan atas kerenggangan hubungan manusia dengan Tuhan, hubungan manusia dengan manusia dan hubungan manusia dengan alam. Sedangkan dehumanisasi hilangnya nilai-nilai luhur kemanusian akibat mementingkan nilai pragmatis, sehingga harkat dan martabat manusia tidak bernilai. Problem lain yang dihadapi pada era industri 4.0 adalah modern berkembangnya mass culture (menjadikan budaya tidak lagi bersifat lokal melainkan nasional atau bahkan global), kecenderungan berfikir rasional, serta sikap hidup materialistis, dimana semua lini kehidupan diukur dengan nilai kebendaan dan ekonomi (Syukur, 2011).

Problematika yang dihadapi manusia seringkali menyebabkan stres serta berdampak pada kesehatan fisik, sosial, intelektual, psikologis, dan spiritualnya. Dalam kondisi demikian, dibutuhkan peran pendidikan dan agama untuk mengembalikan fitrah manusia agar kembali kejalan yang benar, yaitu pengembangan potensi yang dimilikinya.

Pendidikan sebagai payung ilmu pengetahuan yang berorientasi untuk penerapan nilai praksis dan perubahan pola pikir, sikap dan perilaku manusia dari kondisi apa adanya menjadi kondisi sebagaimana mestinya (Kartadinata, 2011). Sebagai upaya mengubah sikap dan perilaku, salah satu komponen penting pendidikan adalah bimbingan dan konseling. Layanan bimbingan dan konseling bertujuan untuk membantu individu mengenal diri serta lingkungan guna pengembangan potensi yang dimiliki agar memperoleh kebahagian hidup

Konseling dalam konteks pendidikan di Indonesia merupakan arena pendukung pengembangan potensi individu yang dilandasi nilai-nilai agama. Bimbingan dan konseling idealnya dijalankan dalam suasana pendidikan dengan mengedepankan hakikat manusia sebagai makhluk ciptaan Tuhan. Melalui pemikiran ini, bimbingan dan konseling seyogyanya dilaksanakan dengan berorentasi pada penanaman keyakinan kepada Tuhan baik fungsi sebagai pencegah (preventive), pengobat (kurative), maupun pengembang (development). Oleh karena itu, sebagai alternatif solusi problematika tersebut diperlukan kolaborasi antara bimbingan dan konseling dengan agama. Kolaborasi dimaksudkan sebagai upaya mengisi kekosongan yang terdapat pada bimbingan dan konseling dengan nilai-nilai yang bersumber pada ajaran agama. Melalui kolaborasi itu diharapkan tercipta bimbingan dan konseling religius sebagai alternatif untuk pengembangan potensi manusia. 
Definisi konseling religius sebagaimana rumusan para ahli adalah hubungan profesional antara konselor dan konseli dalam rangka membantu individu memperdayakan potensi berlandaskan keyakinan pada Tuhan (transenden) (Lines, 2006). Lines menegaskan dalam konseling religius dapat menggunakan beberapa teknik seperti berdo'a (prayer), membaca kitab suci (reading scripture), pemberian maaf (forgiveness), dan meditasi (meditation).

Sementara Richards and Bergin (2006) menggunakan istilah a theistic spiritual strategy untuk menyebut konseling religius. A theistic spiritual strategy diartikan sebagai penanganan dengan menggunakan agama dan spiritual dalam membantu menangani dan memberdayakan potensi konseli, khususnya yang menyangkut dimensi ecumunical dan denominasi spesifik. Konseling theistik dibangun dengan menggunakan sumber daya yang berasal dari beberapa ajaran agama (agama samawi dan agama timur) dan nilai-nilai spiritual. Landasan utama dari konseling theistik adalah mengakui eksistensi Tuhan, manusia adalah ciptaan Tuhan, dan adanya proses spiritual hubungan antara manusia dengan Tuhan. Konseling theistik memanfaatkan sumber daya agama dan spiritual untuk mengatasi problem yang dihadapi individu.

Sementara Yusuf (2009) menyebut konseling religius dengan istilah konseling spiritual theistik yaitu proses bantuan dengan menggunakan pendekatan religius dan nilainilai spiritul. Beberapa asumsi yang mendasarinya meliputi: (a) meyakini Tuhan sebagai dzat Yang Maha Agung, (b) meyakini manusia adalah makhluk Tuhan, (c) keyakinan kepada Tuhan berpengaruh pada pandangan tentang hakikat manusia dan teori kepribadian, (d) keyakinan kepada Tuhan berpengaruh pada pandangan tentang disfungsi manusia dan perubahan teurapetik, (e) keyakinan kepada Tuhan berdampak terhadap hubungan dengan konseli, asesmen, dan intervensi terapeutik, dan (f) keyakinan kepada Tuhan dapat meningkatkan mutu proses terapeutik.

Berdasarkan beberapa definisi di atas, esensi konseling religius adalah proses bantuan untuk mengembangkan potensi individu yang meyakini eksistensi Tuhan dengan memanfaatkan sumber daya yang terdapat dalam ajaran agama. Kemantapan keyakinan kepada Tuhan menjadi inti dari proses konseling religius, sehingga dalam proses pencegahan (preventif), pengentasan masalah (kuratif), maupun pengembangan (development) mengacu pada keyakinan kepada Tuhan. Dengan demikian, konseling religius dapat didefinisikan sebagai proses hubungan profesional antara konselor dan konseli untuk membantu konseli guna mengembangkan potensi secara optimal agar 
memperoleh kebahagiaan saat ini dan masa yang akan datang berlandaskan keyakinan kepada Tuhan.

\section{HASIL DAN BAHASAN}

\section{Landasan Konseling Religius}

Konseling religius dapat kokoh berdiri apabila secara teoritikal mempunyai landasan yang kokoh. Landasan konseling dimaksudkan sebagai dasar sistemik yang gunakan untuk dalam perumusan konsep. Tulisan ini menguraikan lima landasan konseling religius, yaitu: (1) landasan filosofis, (2) landasan regulatif, (3) landasan psikologis, (4) landasan empiris, dan (5) landasan budaya serta pengalaman beragama. Kelima landasan tersebut membentuk satu kesatuan secara integral untuk mewujudkan kemandirian dan pengembanan potensi individu dalam bingkai keyakinan kepada Tuhan.

\section{Landasan Filosofis}

Hakikat manusia dalam perspektif konseling religius adalah makhluk ciptaan Tuhan dengan fitrah (potensi) jasmani dan rohani yang sifatnya saling berkaitan dan utuh (holism). Manusia adalah makhluk yang diberi insting religius (naluri beragam), sehingga dijuluki dengan "homo devians" dan "homo religious" yaitu makhluk yang bertuhan atau beragama (Yusuf, 2017). Disamping itu, manusia adalah makhluk yang memiliki kecerdasan ruhani (Nurihsan, 2007). Potensi yang diberikan kepada manusia berimplikasi terhadap kemampuan memilih yang baik atau buruk sesuai pertimbangan ajaran agama, norma sosialmasyarakat maupun akal sehat. Melalui potensinya manusia harus mempertanggungjawabkan perbuatannya kelak. Perbuatan yang baik (sesuai ajaran agama) akan diberi balasan surga (kenikmatan, kebahagiaan) dan perbuatan buruk (melanggar ajaran agama) diberi balasan neraka (kesengsaraan, kesedihan).

Hakikat manusia di atas berimplikasi pada pengakuan keyakinan kepada Tuhan dan meletakkan Tuhan sebagai pusat hidupnya, sehingga perilaku manusia mengikuti aturan yang sudah ditetapkan oleh Tuhan melalui agama. Landasan filosofis hakikat manusia sebagai makhluk ciptaan Tuhan didasarkan pada beberapa pandangan yaitu: (1) saintifik religius (scintific theism), (2) tesitik yang utuh (theistic holism), (3) agensi (agency), (4) moral universal (moral universalism), (5) teistik rasional (theistic relationism), (6) altruisme (altruism), dan (7) kontekstual (contextuality) (Richards \& Bergin, 2006).

Saintifik religius meyakini kemampuan manusia untuk berkomunikasi dengan Tuhan melalui dimensi spiritual yang dimilikinya. Aksioma yang mendasari pandangan ini adalah Tuhan sebagai pencipta alam semesta dan memberi kehidupan. Manusia untuk 
mengembangkan potensinya bersandar pada ilmu pengetahuan (rasional dan pengalaman) serta membutuhkan dimensi spiritual yang berupa wahyu, intuisi maupun inspirasi. Pandangan ini menolak dengan tegas konsep ateis (tidak mengakui Tuhan). Saintifik religius memberi perhatian pada sifat pluralistik pengetahun yaitu pemerolehan ilmu pengetahuan dapat menggunakan berbagai cara, seperti pendekatan ilmiah maupun pendekatan agama. Implikasi pandanan ini, wahyu dapat dijadikan sebagai sumber pengetahuan dan kebenaran.

Teistik yang utuh (theistic holism) dimaknai sebagai kualitas yang bersifat utuh, sesuatu yang tidak dapat direduksi menjadi bagian-bagian. Dalam pandangan ini diyakini bahwa bagian akan berfungsi tergantung dari keseluruhan. Paham holisme berbeda dari paham atomisme, yang berasumsi bahwa sifat bagian berasal dari penjumlahan dari masingmasing bagian. Manusia adalah makhluk yang memiliki komponen fisiologi, psikologis, jiwa, dan ruhani. Jiwa yang terdapat pada manusia bersifat kekal, meskipun jasad telah hancur akan tetapi jiwa akan tetap hidup sesuai kodratnya. Sebagai kesatuan yang utuh jiwa berinteraksi dan berpengaruh terhadap dimensi lain termasuk fisiologis, kognitif, emosional, interpersonal, dan sistem budaya.

Agensi (agency) merupakan kemampuan manusia memilih tujuan yang bersumber dari pikiran, perasaan, dan tingkah laku. Manusia bukanlah makhluk yang dikendalikan oleh lingkungan, tetapi manusia dianugerahi oleh Tuhan dengan kemampuan menentukan perilakunya. Kebebasan memilih (freedom of choise) dan kebebasan berkeinginan (freedom of willing) menjadi identitas pada manusia.

Moral Universal (moral universalism) dimaknai sebagi moral obyektif yang diyakini oleh semua manusia sebagai nilai kebaikan yang berlaku secara umum dengan tujuan kesejahteraan hidup manusia. Moral universal yang dipegang oleh semua manusia seperti jujur, adil, menghormati orang lain, peduli, kasih sayang, larangan mencuri, larangan membunuh manusia, dan larangan hubungan seksual menyimpang (selingkuh, homoseksual, dan perzinaan).

Keterhubungan teistik (theistic relationism) dimaknai sebagai saling terikat antara sesama manusia, manusia dengan alam semesta, dan manusia dengan Tuhan. Hubungan perspektif ini menegaskan bahwa manusia sebagai makhluk yang menentang egoisme diri sendiri untuk bertahan hidup. Dengan kata lain, manusia adalah satu keluarga yang memiliki ikatan sebagai makhluk ciptaan Tuhan. 
Altruisme (altruism) pada manusia diartikan sebagai makhluk yang memiliki kepekaan sosial untuk berbuat dan memikirkan kebahagiaan orang lain tanpa mengharapkan imbalan atas perbuatannya. Altruisme menjadi landasan dalam konseling theistik yang berbeda dengan pendekatan yang lain, seperti psikoanalis dengan konsep hedonismenya maupun behavioris dengan konsep imbalan (reward) dan hukuman (punishment).

Kontekstual (contextuality) memberikan pemahaman bahwa tingkah laku manusia menyangkut dunia spiritual tidak seperti pada wilayah pengukuran psikologi yang bersifat empiris, dapat diulang, dan dapat digeneralisir. Kontekstual pada pandangan ini menekanakn bahwa pengalaman individu sering bersifat unik, tidak kasat mata, dan tidak dapat digeneralisasi.

Dari uraian pandangan hakikat manusia di atas, proses konseling religius senantiasa merefleksikan kedirian manusia yang dilakukan oleh tenaga profesional untuk membantu memperdayakan potensi individu agar memperoleh kebahagiaan dalam hidupnya. Bantuan kemanusian diarahkan sebagai proses penyadaran individu sebagai makhluk ciptaan Tuhan dan berdasarkan ajaran agama. Landasan filosofis ini menjadi penting dalam konseling religius karena pengakuan eksistensi Tuhan sebagai pencipta manusia, keyakinan Tuhan pengatur keseimbangan alam semesta, dan percaya Tuhan sebagai Kekuatan Maha Agung. Melalui proses konseling religius konseli memiliki keyakinan terhadap kekuasaan Tuhan untuk membantu mengembangkan potensi dan menyelesaikan masalah yang dihadapi (Richards \& Bergin, 2006; Yusuf, 2009).

\section{Landasan Regulatif}

Sebagaimana diuraikan di pendahuluan, secara konstitusi negara Indonesia adalah bangsa yang percaya pada Tuhan dan menjadikan agama sebagai way of live (pedoman hidup). Negara secara tegas dan ekplisit menyebut bahwa kemerdekaan yang diperoleh merupakan rahmat Allah Yang Maha Kuasa. Pengakuan itu tertuang di Pembukaan UndangUndang Dasar Republik Indonesia 1945. Keyakinan terhadap Tuhan dalam kehidupan berbangsa dan bernegara dimunculkan secara tegas dalam sila pertama Pancasila, yaitu Ketuhanan Yang Maha Esa. Sila pertama ini menegaskan bahwa landasan utama dalam kehidupan berbangsa dan bernegara adalah mengakui Tuhan. Kedua landasan konstitusional tersebut memberikan pemahaman bahwa bangsa Indonesia adalah bangsa yang menjunjung tinggi nilai-nilai religius.

Disamping UUD RI 1945 dan Pancasila, landasan kebijakan yang mendasari perlunya penerapan konseling religius adalah amanat Undang-Undang Sistem Pendidikan Nasional 
(UU Sisdiknas) No. 20 Tahun 2003 menyebutkan bahwa arah dan orientasi pendidikan untuk mengembangkan potensi peserta didik untuk memiliki spiritual keagamaan, pengendalian diri, kepribadian, kecerdasan, akhlak mulia (Sisdiknas, 2003). Lebih lanjut ditegaskan dalam UU Sisdiknas, tujuan pendidikan nasional untuk mengembangkan potensi peserta didik agar menjadi manusia yang beriman dan bertakwa kepada Allah, berakhlak mulia, sehat, berilmu, cakap, kreatif, mandiri dan menjadi warga negara yang demokratis serta bertanggungjawab.

Beberapa kebijakan regulatif yang sudah dipaparkan (UUD 1945, Pancasila, dan Undang-Undang Sistem Pendidikan Nasiona) menjadi landasan yang kuat untuk penerapan konseling religius. Landasan regulatif mempunyai arti strategis untuk pengembangan konseling religius dalam konsteks budaya bangsa Indonesia.

\section{Landasan Psikologis}

Manusia dianugerahi kecerdasan spiritual (spiritual quotion) yang diartikan dengan: (1) kemampuan untuk mengenal dan memecahkan masalah-masalah yang terkait dengan makna dan nilai; (2) menempatkan berbagai kegiatan dan kehidupan dalam konteks yang lebih luas, kaya, dan memberikan makna; dan (3) mengukur atau menilai bahwa salah satu kegiatan atau langkah kehidupan tertentu lebih bermakna dari yang lainya (Yusuf \& Nurihsan, 2010). Pakar lain menyebut kecerdasan spiritual dengan kecerdasan ruhaniah (trancendent intelligence) (Tasmara, 2001). Kecerdasan ruhani artikan sebagai kecerdasan yang berpusat pada rasa cinta yang mendalam kepada Allah Rabbul 'Alamin dan seluruh ciptaan-Nya.

Dengan berbekal pada kecerdasan ruhaniah, memungkinkan manusia berkomunikasi dengan Tuhan. Esensi kecerdasan ruhaniaah ini sebagai wujud cinta kasih Tuhan pada manusia agar dapat kembali ke alam ruhani sebagaimana manusia pertama kali diciptakan di surga. Fitrah ruhani disematkan kepada manusia sebagai rencana Tuhan agar menjadi khalifah di muka bumi dan dapat kembali ke surga. Kecerdasan ruhani sebagai kesadaran tertinggi yang bersumber dari keimanan kepada Allah SWT.

Kecerdasan ruhaniah yang dimiliki oleh manusia ditopang dengan berbagai atribut kecerdasan lainya, seperti kecerdasan intelektual dan kecerdasan emosional. Kecerdasan intelektual membantu manusia mengelola akalnya untuk menimbang hal yang baik dan buruk, sementara kecerdasan emosional dimanfaatkan untuk mengelola rasa apakah sesuai dengan norma atau bertentangan dengan norma. Semua kecerdasan yang dimiliki oleh manusia digunakan dengan seoptimal mungkin untuk membantu tugas perkembangan (fisik, 
bahasa, sosial, karir maupun agama) yang perlu diselesaikan oleh setiap manusia. Tugas perkembangan dalam dimensi agama membawa konsekuensi agar manusia mampu memahami dirinya dan memahami Tuhan dengan baik, serta memahami ajaran agama guna diterapkan dalam kehidupan.

\section{Landasan Empiris}

Temuan mutakhir pentingya konseling religius terangkum dalam dua hal, yaitu (1) pengaruh agama terhadap kesehatan mental dan fisik dan (2) pengaruh pemanfaatan sumber daya religius terhadap kesehatan fisik, mental, dan kesejahteraan individu.

Bukti empiris pengaruh agama terhadap kesehatan mental berkembang signifikan selama beberapa dekade terakhir. Penelitian korelasional antara variabel agama (spiritual) terhadap kesehatan mental banyak dilakukan para ahli, diantaranya pengaruh religiusitas terhadap kesehatan mental (Kokenig, 2009; Snider \& McPhedran, 2014), religiusitas dan kebahagiaan pada mahasiswa (Wahidin, 2017), hubungan Islam dengan perilaku manusia, patologi, kesehatan, dan spiritualitas (Keshavarzi \& Haque, 2013), dan perspektif Islam tentang kesehatan mental dan psikoterapi (Farooqi, 2006). Hasil studi Yusuf menyebutkan bahwa individu yang taat beribadah memiliki kecenderungan : (1) rendah untuk terserang penyakit fisik seperti hati, jantung, hipertensi, disfungsi sistem kekebalan tubuh, dan kanker; (2) memiliki usia hidupnya lebih lama; dan (3) menjauhi perilaku yang tidak sehat, seperti merokok, minum minuman keras, mengkonsumsi obat terlarang, dan berhubungan seks di luar nikah [22]. Richard dan Bergin juga menyebut hubungan positif antara agama dan konseling dalam tiga hal, yaitu : (1) perilaku koping agama (religius coping behaviors) membantu klien ketika mengalami stres dan sakit; (2) orang beragama memiliki kesehatan fisik yang lebih baik, panjang umur, lebih cepat pemulihan pasca operasi, tumbuhnya kesejahteraan, kepuasan hidup, bermoral, empati, dan altruisme; dan (3) orang beragama memiliki kecemasan yang rendah terkait dengan kematian, kecemasan, rasa bersalah, depresi, dan kecenderungan bunuh diri, cenderung tidak bercerai, tidak menggunakan alkohol atau obat-obatan, tidak melakukan kehamilan pranikah, dan kenakalan (Richard \& Bergin, 2006).

Dari beberapa temuan riset di atas semakin memperkokoh posisi agama dalam meningkatkan kesehatan fisik maupun mental manusia. Pengaruh tersebut sejalan dengan arti penting agama sebagai pandangan dunia (way of live) dan sistem kepercayaan (Barnett \& Johnson, 2011). Keyakinan atau agama dapat berfungsi sebagai sumber kekuatan, dukungan, dan inspirasi bagi proses (Nickles, 2011). 
Sementara itu, bukti empiris pengaruh penggunaan sumber daya religius bagi peningkatan kesehatan mental dapat dilacak dari beberapa hasil penelitian, diantaranya: (1) coping religius positif yang lebih tinggi berpengaruh terhadap ketabahan spiritual (McElroy-Heltzel et al., 2018); coping religius sebagai metode penyembuhan kanker (Nikfarid et al., 2018); coping religious sebagai intervensi bagi pemabuk, pengguna ganja, dan penggunaan psikostimulan (Giordano et al., 2015).

Disamping itu, bukti empiris tentang usaha untuk mewujudkan konseling religius bagi pengembangan potensi individu dapat ditelusuri dari beberapa hasil penelitian sebagai berikut: (1) perspektif Islam tentang kesehatan mental dan psikoterapi (Farooqi, 2006); (2) integrasi spiritual dengan psikoterapi dalam perspektif Islam melalui pendekatan kognitif (Hamdan, 2008); (3) sakralitas agama dalam psikoterapi (Post \& Wade, 2009); (4) integrasi spiritual dan religious dalam psikoterapi (Utsch, 2007; Smith et al., 2007); (5) penerapan kurikulum konseling religius bagi konselor (Hofmann \& Walach, 2011); (6) persepsi klien tentang dan pengalaman dengan intervensi religius dalam psikoterapi (Martinez et al., 2007); (7) efektivitas konseling kelompok dengan pendekatan spiritual (Cornish \& Wade, 2010); dan (8) etika psikoterapi dalam konseling religius (Barnett \& Johson, 2011).

Berdasar studi yang dilakukan Smith et al. disimpulkan bahwa (a) konseling yang berorientasi religius sama efektif dengan pendekatan lain, dan terkadang lebih efektif bagi konseli yang religius dibandingkan dengan pendekatan sekuler. Beberapa temuan di atas memberi gambaran tentang signifikansi konseling religius bagi kesehatan manusia. Implementasi konseling religius dapat dilakukan dalam berbagai intervensi, seperti psikoterapi religius, coping religius, maupun penggunaan sumber religius (Martinez et al., 2007).

5. Landasan Budaya dan Pengalaman Beragama

Secara budaya masyarakat Indonesia memiliki religiusitas yang tinggi, pernyataan ini dapat dibuktikan dari sila pertama Pancasila dan perilaku masyarakat yang senantiasa terkait dengan nilai-nilai religius. Sebagian masyarakat Indonesia percaya pada hal-hal ghaib, melakukan ziarah kubur, melakukan tirakat, dan sebagainya. Perilaku beragama tersebut mengindikasikan bahwa pengalaman beragama memiliki nilai penting bagi landasan konseling religius.

Pengalaman beragama sebagai salah satu atribut psikologi seseorang yang berfungsi sebagai kesadaran individu dalam menghormati keberadaan alam sejagat raya. Penghormatan ini dikaitkan dengan kekuatan tertinggi dalam kehidupan ini (transenden), 
seperti Tuhan, keabadian, puncak kebenaran tertinggi, nilai-nilai luhur, sesuatu yang bermakna. Dengan pengalaman bergama akan memberi inspirasi tentang perasaan keberdayaan, harapan, kerendahan hati, dan takjub (Eude, 2008). Karakteristik inti dari orang tertanamnya pengalaman beragama ialah mereka menikmati secara penuh kasih sayang, kedekatan yang tulus, dan keharmonisan.

Pengalaman beragama muncul melalui identitas agama pada diri individu. Individu yang mampu menerjemahkan agama dalam kehidupan sebagai identitas diri, maka perilakunya akan dilekatkan dengan nilai-nilai agama, sehingga membetuk pengalaman bergama yang kompleks. Faktor pembentuk identitas beragama adalah ajaran agama itu sendiri dan budaya (Berkel et al., 2004). Pengalaman beragama tidak bisa lepas dari budaya, karena budaya secara langsung berpengaruh terhadap cara hidup, cara berpikir, bersikap dan bertingkah laku (Koentjaraningrat, 2009).

Pengalaman beragama merupakan fenomena kehidupan manusia bahkan merupakan keniscayaan yang selalu dicari oleh manusia. Pengalaman beragama pada manusia bukan semata persoalan pencarian arah hidup yang bertumpu pada ruhani, tetapi hubungan yang lekat sebagai sumber nilai dan sumber kognitif. Pengalaman beragama sebagai sumber nilai akan melahirkan norma-norma yang diinternalisasikan kedalam kehidupan sehari-hari yang akan memunculkan kesadaran beragama (Drajat, 2010), yaitu keyakinan yang dihasilkan oleh tindakan atau amaliah individu dalam menjalankan agamanya.

Proses dialektika agama dan budaya dalam bahasa antropologi disebut eksternalisasi, objectivisasi, dan internalisasi (siapa membentuk apa, dan apa berpengaruh pada siapa) . Eksternalisasi merupakan proses pencurahan potensi manusia secara terus-menerus melalui aktivitas fisik dan mental terhadap nilai yang diyakini sebagai kebenaran. Obyektivitas diartikan sebagai aktivitas manusia untuk menemukan realita objektif yang berada di luar diriya dan membentuk kesadaran diri. Internalisasi merupakan penyerapan realitas objektif dan kebenaran hasil kesadaran diri dalam bentuk perilaku.

Melalui ketiga tahap tersebut, dialektika antara agama dan budaya membawa konsekwensi memunculkan perilaku beragama di masyarakat yang dipetakan menjadi dua, yaitu high tradition (pemurnian agama) dan low tradition (pencampuran agama dengan budaya). Perilaku beragama dalam kategori high tradition diekspresikan melalui teguhnya penerapan agama sesuai dengan ajaran kitab suci, sedangkan perilaku beragama low tradition mengakomodir budaya yang disesuaikan dengan ketentuan kitab suci. Hasil 
dialektika perilaku beragama di Islam memunculkan istilah Islam puritan, Islam moderat, dan Islam ekstrim.

\section{Kompetensi Religius}

Konselor sebagai tenaga profesional yang bertugas untuk mengembangkan potensi dan memandirikan konseli perlu dibekali seperangkat kemampuan untuk menjalankan tugas pokoknnya. Kompetensi konselor sebagaimana ditetapkan dalam Permendiknas Nomor 27 Tahun 2008 terdiri dari empat kompetensi, yaitu pedagogik, kepribadian, sosial, dan profesional. Masing-masing empat kompetensi tersebut mempunyai kualifikasi dan standar yang berbeda-beda dan menjadi satu kesatuan untuk mendukung tugas pokok sebagai konselor.

Agar konselor dapat menjalankan tugasnya dengan baik dalam pendekatan ini perlu tambahan kompetensi religius. Kompetensi religius sebagai nilai tambah disamping penguasaan empat kompetensi yang sudah disebutkan di atas. Kompetensi religius diartikan sebagai seperangkat kemampuan yang dimiliki konselor dalam memahami agama secara komprehensif, baik terefleksi dalam pengetahuan maupun perilakunya. Kompetensi religius sebagai ciri pembeda yang harus dimiliki konselor dengan pendekatan konseling umum. Kompetensi religius didalamnya memuat: (1) pemahaman tentang hakikat manusia dalam perspektif religius, (2) pemanfaatan sumber daya religius, (3) dan penerapan coping religius dalam proses konseling.

Kompetensi religius dapat dirumuskan dalam beberapa uraian detail sebagai berikut: (1) memahami hakikat manusia sebagai makhluk ciptaan Tuhan; (2) meyakinkan kepada konseli bahwa Tuhan sebagai penolong manusia; (3) membimbing kehidupan religius konseli selama proses konseling; (4) menjadi inspiraitor bagi konseli selama proses konseling; (5) mengembangkan diri sebagai fasilitator untuk memberikan layanan konseling; (6) menerapkan karakteristik profesional konselor umum (memiliki kesehatan psikologis yang baik, mempunyai kesadaran diri, pikiran terbuka, berempati, pandangan tak bersyarat terhadap hal positif, bersifat asli (genuineness) dan kesesuaian (congruence), serta tidak menghakimi); (7) menggunakan sumber daya religius dalam proses konseling; dan (8) menerapkan coping religius untuk membantu konseli.

\section{Tantangan Konseling Religius}

Pelaksanaan bimbingan dan konseling pada dunia pendidikan di Indonesia, mayoritas guru pembimbing atau konselor sekolah lebih memilih memaki pendekatan bimbingan dan konseling umum atau sekuler. Karakteristik utama bimbingan dan konseling umum adalah 
kurang menekankan keyakinan konseli kepada Tuhan YME, baik dalam masalah yang dihadapi, proses penyelesaian, maupun hasil perubahan yang akan dicapai. Dengan kata lain, bimbingan dan konseling umum kering nilai-nilai religius dan spiritual. Maraknya penggunaan bimbingan dan konseling umum disebabkan karena adanya hambatan (barries) dalam implementasi bimbingan dan konseling religius. Beberapa hambatan yang ada dapat disebutkan antara lain: (1) sebagian konselor Barat melihat religius sebagai sesuatu yang kurang pas diterapkan dalam konseling (Richard \& Potts, 1995); (2) ketakutan sebagian konselor untuk menggunakan religius pada proses konseling (Richards \& Bergin, 2006); (3) rata-rata konselor di Barat kurang religius dan tidak meyakini agama (Delaney et al., 2007; Shafanske \& Cummings, 2013); dan (4) minimnya pelatihan tentang konseling religius (Cornish \& Wade, 2010).

Beberapa hambatan tersebut menjadikan konseling religius kurang diminati oleh guru pembimbing maupun konselor sekolah. Khusus untuk solusi minimnya pelatihan konseling religius dapat diantisipasi dengan pembukaan program pelatihan tentang penerapan konseling religius. Program pelatihan konseling religius dimaksudkan sebagai upaya pemenuhan pendekatan konseling yang sesuai dengan falsafah dan budaya religius yang dimiliki oleh bangsa Indonesia.

\section{KESIMPULAN}

Uraian di atas menyiratkan urgensi konseling religius yang berlandaskan pada filosofis, regulatif, empiris, psikologis, budaya dan pengalaman beragama. Landasan filosofis sebagai pusat penerapan konseling religius dengan menempatkan manusia sebagai ciptaan Tuhan, keyakinan pada Tuhan dan ketundukan aturan yang ditetapkan Tuhan. Urgensi bimbingan dan konseling religius juga ditopang dengan kebijakan yang telah ditetapkan oleh pemerintah, baik melalui Undang-Undang maupun peraturan pemerintah lainya. Agar implementasi konseling religius dapat terwujud, maka dalam tataran teknis penambahan kompetensi religius pada konselor perlu dimasukkan dalam kurikulum pendidikan calon konselor atau guru pembimbing.

\section{DAFTAR RUJUKAN}

Barnett, J. E. \& Johnson, W. B. (2011). Integrating Spirituality And Religion Into Psychotherapy: Persistent Dilemmas, Ethical Issues, And A Proposed DecisionMaking Process. Ethics Behavior, 21(2), 147-164.

Berkel, L. A., Armstrong, T. D., \& Cokley, K. O. (2004). Similarities and Differences Between Religiosity and Spirituality in African American College Students: A Preliminary Investigation. Counseling Values, 49(2), 1-49. 
Cornish, M. A. \& Wade, N. G. (2010). Spirituality and Religion in Group Counseling: A Literature Review With Practice Guidelines. Professional Psychology: Research and Practice, 41(5), 398-404.

Dahlan, M. (2011). Posisi Bimbingan dan Konseling dalam Kerangka Ilmu," in Pendidikan dalam Perspektif Bimbingan dan Konseling, Suherman and N. Budiman, Eds. Bandung: UPI Press.

Darajat, Z. (2010). Ilmu Jiwa Agama. Jakarta: Bulan Bintang.

Delaney, H. D., Miller, W. R., \& Bisonó, A. M. (2007). Religiosity and Spirituality Among Psychologists: A Survey of Clinician Members of the American Psychological Association. Professional Psychology: Research and Practice, 38(5), 538-546.

Eude, T. (2008). Children's Spiritual, Moral, Social and Cultural Development: Primary and Early Year. British: Learning Matters.

Fanani, M. (2008) Membumikan Hukum Langit; Nasionalisasi Hukum Islam dan Islamisasi Hukum Nasional Pasca Reformasi. Yogyakarta: Tiara Wacana.

Farooqi, Y. N. (2006). Understanding Islamic Perspective of Mental Health and Psychotherapy. Journal Psychology Africa, 16(1), 101-111.

Giordano et al., A. L. (2015). Exploring the relationship between religious coping and spirituality among three types of collegiate substance abuse," Journal Counseling and Development, 93(1), 70-79.

Hamdan, A. (2008). Cognitive restructuring: An Islamic perspective. Journal Muslim Mental Health, 3(1), 99-116.

Hofmann, L. \& Walach, H. (2011). Spirituality and religiosity in psychotherapy-a representative survey among German psychotherapists," Psychotheraphy Research, 21(2), 179-192.

Kamaruddin. (2013). Dimensi Sila 'Ketuhanan Yang Maha Esa' Dalam Perspektif HAM Islam. IN RIGHT: Jurnal Agama dan Hak Azazi Manusia, 3(1), 163-178.

Kartadinata, S. (2011). Menguak Tabir Bimbingan dan Konseling Sebagai Upaya Paedagogis, Kiat Mendidik Sebagai Landasan Profesional Tindakan Konselor. Bandung: UPI Press.

Keshavarzi, H. \& Haque, A. (2013). Outlining a Psychotherapy Model for Enhancing Muslim Mental Health Within an Islamic Context. The International Journal for Psychology of Religion, 23(3), 230-249.

Koenig, H. G. (2009). Research on Religion, Spirituality, And Mental Health: A Review. Can: Journal of Psychiatry, 54(5), 283-291.

Koentjaraningrat. (2009). Gotong Rojong: Some Social-anthropological Observations on Practices in Two Villages of Central Java.2009 (originally published by Cornell Southeast Asia Program, Cornell University, 1961). Singapore: Equinox Publishing.

Lines, D. (2006) Spirituality in Counselling and Psychotherapy Introduction. London: SAGE Publication Ltd., 2006.

Martinez, J. S., Smith, T. B., \& Barlow, S. H. (2007). Spiritual Interventions in Psychotherapy: Evaluations by Highly Religious Clients, Journal of Clinical Psychology, 63(10), 41-60.

McElroy-Heltzel, S. E. et al. (2018). The Role of Spiritual Fortitude and Positive Religious Coping in Meaning in Life and Spiritual Well-Being Following Hurricane Matthew. Journal of Psycholgy and Christianity, 37(1), 17-27.

Nickles, T. (2011). The role of Religion and Spirituality in Counseling. California: California Polytechnic State University.

Nikfarid, L., Rassouli, M., Borimnejad, L., Alavimajd, H. (2018). Religious Coping in Iranian Mothers of Children With Cancer: A Qualitative Content Analysis. Journal 
Pediatric Oncology Nursing, 35(3), 188-198.

Nurihsan, A. J. (2007). Strategi Layanan Bimbingan dan Konseling. Bandung: PT Refika Aditama.

Pambudi, W. (2018). Sakralisasi Pembukaan UUD 1945. ISTORIA: Jurnal Pendidikan dan Sejarah, 4(1), 1-12.

Post, B. C. \& Wade, N. G. (2009). Religion and Spirituality in Psychotherapy: A PracticeFriendly Review of Research. Journal Clinical Psycholgy, 65(2), 41-60.

Richards, P. S. \& Potts, R. W. (1995). Using Spiritual Interventions in Psychotherapy: Practices, Successes, Failures, and Ethical Concerns of Mormon Psychotherapists," Professional Psychology: Research and Practice, 26(2), 163-170.

Richards, P. S. and Bergin, A. E. (2006). A spiritual strategy for counseling and psychotherapy, 2nd. Washington, DC: American Psychological Association.

Satya, V. E. (2018). Strategi Indonesia Menghadapi Industri 4.0. Info Singkat: Kajian Singkat terhadap Isu Aktual dan Strategis. Jakarta: Pusat Penelitian Badan Keahlian DPR-RI.

Shafranske, E. P., \& Cummings, J. P. (2013). Religious and spiritual beliefs, affiliations, and practices of psychologists. In K. I. Pargament, A. Mahoney, \& E. P. Shafranske (Eds.), APA handbook of psychology, religion, and spirituality (Vol. 2): An applied psychology of religion and spirituality, 23-41. DOI: 10.1037/14046-002

Smith, T. B., Bartz, J., \& Richards, P. S. (2007). Outcomes Of Religious And Spiritual Adaptations To Psychotherapy: A Meta-Analytic Review, Psychotherapy Research, 17(6), 643-655.

Snider, A. M. \& McPhedran, S. (2014). Religiosity, Spirituality, Mental Health, And Mental Health Treatment Outcomes In Australia: A Systematic Literature Review. Mental Health Religious Culture, 17(6), 568-581.

Sutoyo, A. (2007). Bimbingan dan Konseling Islami (Teori \& Praktik). Semarang: Cipta Prima Nusantara.

Syukur, A. (2011). Sufi Healing; Terapi dengan Metode Tasawuf. Semarang: Walisongo Press.

Tasmara, T. (2001). Kecerdasan Ruhani (Transcendent Intelligence). Jakarta: Gema Insani Press.

Ulfiah, U. (2018). Penanganan Perilaku Bullying Siswa Melalui Konseling Model Pengembangan Komitmen Beragama. Psympathic: Jurnal Ilmu Psikologi, 1(1), 6774.

Utsch, M. (2007). The Challenge Of Psychotherapy For Religion And Spirituality, Psyche \& Geloof, 18(1), 86-95.

Wahidin. (2017). Spiritualitas Dan Happiness Pada Remaja Akhir Serta. Journal Innovation Counseling Theory and Practice, 1(1), 57-66.

Yusuf, S. (2009). Konseling Spiritual Teistik. Bandung: UPI Press, 2009.

Yusuf, S. (2017). Psikologi Perkembangan Anak \& Remaja. Bandung: Remaja Rosda Karya, 2017.

Yusuf, S. (2018). Kesehatan Mental Perspektif Psikologi dan Agama. Bandung: PT Remaja Rosdakarya.

Yusuf, S., \& Nurihsan, J. (2010). Landasan Bimbingan dan Konseling. Bandung: PT Remaja Rosda Karya. 